\title{
MMP activity detection in zymograms
}

Péter Bencsik ${ }^{1,2}$, Monika Bartekova ${ }^{3,4}$, Anikó Görbe ${ }^{1,2}$, Krisztina Kiss $^{1}$, János

Pálóczi $^{2}$, Jana Radosinska ${ }^{3.4}$, Gergő Szűcs ${ }^{1}$, and Péter Ferdinandy ${ }^{2,5}$

${ }^{1}$ Department of Biochemistry, Faculty of Medicine, University of Szeged, Hungary

${ }^{2}$ Pharmahungary Group, Szeged, Hungary

${ }^{3}$ Institute for Heart Research, Slovak Academy of Sciences, Slovak Republic

${ }^{4}$ Institute of Physiology, Faculty of Medicine, Comenius University in Bratislava,

Slovak Republic

${ }^{5}$ Department of Pharmacology and Pharmacotherapy, Semmelweis University, Budapest, Hungary

\section{Address for correspondence:}

Péter Bencsik MD, PhD

Cardiovascular Research Group, Department of Biochemistry, Faculty of Medicine, University of Szeged

Dom ter 9, H6720 Szeged, Hungary

Tel: +36 62545096

Fax: +36 62545097

E-mail: bencsik.peter@med.u-szeged.hu 


\section{Summary}

Matrix metalloproteinases (MMP) belong to a distinguished class of zinc-depending endopeptidases. Zymography is a semi-quantitative tool for determining the activity of different MMP isoenzymes in a variety of biological samples. In substrate gel zymography, protein samples of different origin (tissue, cell lysates, plasma/serum, perfusates, other liquids) are separated in sodium dodecyl sulfate (SDS) polyacrylamide gels containing co-polymerized substrate (gelatin, casein, elastin, etc.), and after incubation enabling substrate cleavage by MMPs, MMP activities are detected after the gel staining as transparent bands against a dark-blue background. In situ zymography is a histological modification of substrate zymography in frozen sections, allowing detection of the localization of the MMP activities within the tissue. Here we describe detailed experimental protocols of all abovementioned techniques and provide examples of several sample measurements.

Key words: matrix metalloproteinase activity, substrate zymography, gelatin, casein, in situ zymography 


\section{Introduction}

\subsection{Matrix metalloproteinases in health and disease}

Matrix metalloproteinases (MMPs) are enzymes that belong to the family of zincdependent endopeptidases and are known to play a crucial role in the dynamic processing of the extracellular matrix (ECM) facilitating the degradation of matrix material. On the other hand, MMPs have been also shown to be present intracellularly, thereby influencing physiological as well as pathological intracellular signal transduction processes and the contractile machinery. Therefore, MMPs are interesting drug targets for several pathologies (see for a review: (1)). The family of MMPs include close to 30 members (see for reviews: $(2,3)$ ), many of them shown to be activated due to different physiological as well as pathological situations in different tissues. Some of the important family members together with their characteristic features are shown in Table 1. MMPs are synthesized as zymogens and can be activated by proteolytic cleavage of an amino-terminal domain, by oxidative/nitrosative-induced conformational change (without a change in molecular weight), or by phosphorylation $(2,4)$. Activities of MMPs are tightly regulated by their endogenous tissue inhibitors (TIMPs) (5).

\section{TABLE 1}

MMPs play an important role in many physiological and pathological processes, including embryogenesis, wound healing, inflammation, cardiovascular diseases and tumor development or progression $(2,6)$. Increased activities of different MMPs have been reported to be connected with different pathological situations such as ischemia-reperfusion injury (7), myocardial contractile dysfunction (8), heart failure (9), arthritis (10), neurodegenerative disorders (11), cancer invasion and metastasis 
(12), liver cirrhosis (13), fibrotic lung disease (14), periodontal disease (15) as well as with responses to some invasive interventions like anthracycline treatment $(\mathbf{1 6 , 1 7 )}$ or chest irradiation (18) used in the cancer therapy. On the other hand, inhibition of MMP activities has been shown to be connected with some kinds of tissue protection such as ischemic preconditioning $(\mathbf{1 9 , 2 0 )}$ or flavonoid-induced cardioprotection $\mathbf{( 1 7 ) . ~}$ Moreover, pharmacological inhibition of MMP activities has been shown to be cardioprotective in animal models of acute myocardial infarction $(\mathbf{2 1 , 2 2 )}$ and has also been shown to be altered in coronary artery disease patients (23). Being able to detect MMPs at early stages of the disease is opening a perspective to use MMPs as diagnostic markers. MMPs have been well-investigated in clinical studies of cardiovascular diseases: MMP-2 and -9 in Chagas cardiomyopathy (24) and MMP-9 in ST-segment elevation myocardial infarction (25). Protein expression and activation of MMP-2 and MMP-9 has clinical relevance and prognostic value in patients with colorectal cancer (26). Fecal MMP-9 is a useful tool for the differential diagnosis of diarrheic disorders and in the non-invasive evaluation of disease activity and mucosal healing in ulcerative colitis (27).

Regarding to the abovementioned facts, determination of MMP activities belongs to very useful methodologies in biomedical research and is of high clinical importance since it seems to be a powerful diagnostic and/or therapeutic tool for the detection or follow-up of the abovementioned pathologies.

\subsection{MMP activity detection in biological samples}

MMP activities can be determined by zymography in different kinds of biological samples such as heart, brain, liver, lung tissues, blood vessels or in isolated or cultured cell lineages (see Fig. 1-3). Zymography can be performed as a substrate zymography, in which the substrate of the certain MMP is incorporated, co- 
polymerized in a sodium dodecyl sulfate (SDS) polyacrylamide gel and MMPs are separated according to their molecular weights. The activity of MMPs is detected by the absence of gelatin in the gel, which can be visualized by transilluminating the gel. The activity of the certain MMP is proportional with the intensity and the thickness of the corresponding band on zymogram, which can be evaluated electronically by using different software after scanning the gels.

\section{FIG $1+2$}

For the detection of MMP activity in situ in different cell or tissue cultures, in situ zymography is a suitable method (Fig. 3). In in vivo systems, natural inhibitors of MMPs (tissue inhibitors of MMPs, TIMPs) are presented (28). Therefore, when a study is designed for detecting MMPs activity in a certain physiological or pathological condition, one should calculate not only with the activation, but the inhibition of MMPs by TIMPs as well. For this reason, reverse zymography has been developed, which allows detection of TIMPs activities in gel zymograms. However, this chapter is limited for showing the opportunities to detect MMP activities in biological samples, thus here we do not provide detailed description on the available techniques for detecting TIMPs activity [for TIMP measurements, see for review (29)].

\section{FIG 3}

\section{$1.3 \quad$ Types of zymography substrates}

MMPs cleave different substrates, therefore, the substrate, which is co-polymerized in the gel, should be determined according to the MMP isoform.

Gelatin zymography is predominantly used for measurements of activities of MMP-2 and MMP-9 as these two MMPs exert strong ability to cleave gelatin as a substrate, and are commonly called "gelatinases". 
In casein zymography, casein is co-polymerized into the polyacrylamide gel as a substrate for MMP cleavage. Casein zymography is used for estimation of proteolytic activity of MMP-7 due to its ability to cleave casein.

The most rarely applied type of zymography is elastin zymography, in which soluble elastin is co-polymerized in the gel and beside the activity of elastases it can suitably show elastinolytic activity for such MMPs, which cleave basically other substrates like gelatin (e.g. MMP-2).

\section{Materials}

\subsection{Sample preparation}

For pulverized tissue samples

1. Homogenization buffer: $500 \mathrm{~mL}$ double distilled water (ddH2O), $0.335 \mathrm{~g}(50 \mathrm{mM})$ Tris base, $1 \mathrm{~mL}$ (0.5\%) Triton X-100. In $500 \mathrm{~mL}$ beaker dissolve compounds in 500 $\mathrm{mL}$ ddH2O. Adjust to $\mathrm{pH} 7.4$ with $1 \mathrm{M} \mathrm{HCl}$. Aliquot into $15 \mathrm{~mL}$ Falcon tubes. Store at $20^{\circ} \mathrm{C}$ for 1 year. Homogenator: Pellet Pestle Motor, Centrifuge (e.g. Hettich Universal 320R), BCA Protein Assay Kit for protein measurement.

For organ perfusates

2. Concentrating tubes: Amicon Ultra-4 $30 \mathrm{kDa}$ centrifugal filter unit with Ultracel-30 membrane for perfusate concentration.

For cell culture lysates

3. Phosphate Buffered Saline tablets (PBS): In $200 \mathrm{~mL}$ beaker dissolve 1 PBS tablet in $100 \mathrm{~mL}$ dd $\mathrm{H} 2 \mathrm{O}$ Adjust to $\mathrm{pH} 7.2$ with $1 \mathrm{mM} \mathrm{NaOH}$ prepare freshly; Homogenization buffer (see above step 1); Amicon Ultra 10 kDa concentrating tubes. Centrifuge (e.g. Hettich Universal 320R) 


\subsection{Gelatin zymography}

$130 \%$ Acrylamide / 0.8\% Bisacrylamide, Store: at $+4{ }^{\circ} \mathrm{C}$ for 1 year.

2 Separating Gel Solution $-1.5 \mathrm{M}$ Tris $\mathrm{HCl}, \mathrm{pH} 8.8$, Store at $+4{ }^{\circ} \mathrm{C}$ for 1 year.

$32 \%$ Gelatin Solution: $100 \mathrm{mg}$ gelatin (type A, from porcine skin; stored at room

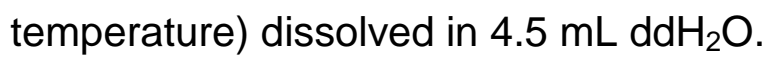

$410 \%(w / v)$ SDS (sodium dodecyl sulfate) solution. Weigh $10 \mathrm{~g}$ SDS and dissolve

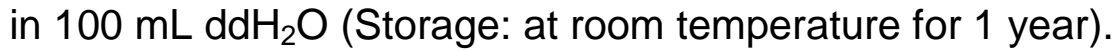

$510 \%(w / v)$ ammonium persulfate (APS) solution: Dissolve $100 \mathrm{mg}$ of APS in $1 \mathrm{~mL}$ ddH2O. Storage: at $+4^{\circ} \mathrm{C}$ for 1 month

6 TEMED. Storage: at $+4{ }^{\circ} \mathrm{C}$ for 1 year.

7 Stacking Gel Solution: $0.5 \mathrm{M}$ Tris HCl/SDS, $\mathrm{pH}$ 6.8. Storage: at $+4{ }^{\circ} \mathrm{C}$ for 1 year.

8 ELFO Buffer (25 mM Tris-HCl, $192 \mathrm{mM}$ glycine, 0.1\% SDS, pH 8.3). Storage: at $+4{ }^{\circ} \mathrm{C}$ for 1 year. Or self prepared: $28.83 \mathrm{~g}$ glycine, $6.0 \mathrm{~g}$ Tris base, $2.0 \mathrm{~g}$ SDS.

Dissolve Tris base and glycine in $1000 \mathrm{~mL}$ of $\mathrm{ddH}_{2} \mathrm{O}$. Bring solution to $1950 \mathrm{~mL}$ with $\mathrm{dd}_{2} \mathrm{O}$. Add SDS. Bring solution to $2000 \mathrm{~mL}$ total volume with $\mathrm{dd}_{2} \mathrm{O}$. Storage: at $4^{\circ} \mathrm{C}$ for 1 year.

9 Non-reducing loading (sample) buffers: use commercial "Blue" Zymogram Sample Buffer or commercial "Pink" non-reducing lane marker.

10 For positive control, use "zymography standard", containing a mixture of purified and activated MMP-2 and MMP-9; or MMP-2 standard for gelatin and elastin zymography (Fig 1A). For casein zymography, human, recombinant active MMP-7 can be used.

11 Renaturation solution: Renaturation buffer (Bio-Rad). Store: at $+4{ }^{\circ} \mathrm{C}$ for 1 year.

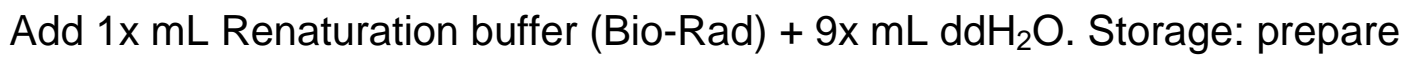
freshly. 
12 Development solution: Development buffer (Bio-Rad) Storage: at $+4{ }^{\circ} \mathrm{C}$ for 1 year. Add 1x mL Development buffer $+9 x \mathrm{~mL} d d \mathrm{H}_{2} \mathrm{O}$. Storage: prepare freshly.

13 For negative control, use $10 \mathrm{mM}$ ethylene glycol tetraacetic acid (EGTA, binds $\mathrm{Ca}^{2+}$ ions, which is obligatory for activity of MMPs). Dissolve $381 \mathrm{mg}$ EGTA in 90

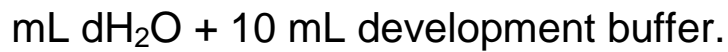

14 Coomassie Brilliant Blue (0.05\%): 250 mg Coomassie Brilliant Blue G-250, 125 $\mathrm{mL}$ methanol, $50 \mathrm{~mL}$ glacial acetic acid, $325 \mathrm{~mL}$ ddH2O. Dissolve $250 \mathrm{mg}$ Coomassie Brilliant Blue in the mixture of $125 \mathrm{~mL}$ methanol and $50 \mathrm{~mL}$ glacial acetic acid and dilute it by adding $325 \mathrm{~mL}$ ddH2O. Storage: at room temperature.

15 Destaining solution: $40 \mathrm{~mL}$ methanol, $80 \mathrm{~mL}$ acetic acid, $880 \mathrm{~mL}$ ddH2O. Storage: at room temperature

\subsection{Casein zymography}

All materials and procedures are identical with gelatin zymography except gelatin solution, which is substituted with casein.

1 Casein solution: $100 \mathrm{mg}$ casein (storage: at room temperature) dissolved in 4.5 $\mathrm{mL}$ phosphate buffer.

2 Phosphate buffer (126 mM)

\subsection{Elastin zymography}

All materials and procedures are identical with gelatin zymography except gelatin solution, which is substituted with elastin.

Elastin solution: $54 \mathrm{mg}$ soluble elastin from bovine neck ligament dissolved in 4.5 $\mathrm{mL} \mathrm{ddH} \mathrm{H}_{2} \mathrm{O}$.

\subsection{Materials for in situ zymogrpahy}


EnzCheck Gelatinase/Collagenase Assay Kit (Invitrogen)

Assay includes the following reagents:

DQ gelatine from pig skin: five vials (1mg DQ substrate lyophilized from $1 \mathrm{~mL}$ of PBS in each vial).

10x Reaction Buffer: $50 \mathrm{~mL}$

1,10 o-phenanthroline monohydrate: $30 \mathrm{mg}$ powder in a vial.

Collagenase type IV. from Clostridium Histolyticum: 500 collagenase powder in a vial.

\section{Methods}

\subsection{Sample preparation}

\section{Pulverized tissue sample}

1. Weigh out 30-50 mg heart (lung, pancreas, aorta, spleen) tissue powder into a liquid-nitrogen-frozen $1.5 \mathrm{~mL}$ Eppendorf tube. Avoid thawing. It can be stored at $-80^{\circ} \mathrm{C}$ for 2 years.

2. Thaw an appropriate amount of homogenization buffer (see Note 1).

3. Add $4 \times$ volume homogenization buffer to the sample (e.g. $30 \mathrm{mg}$ sample and $120 \mu \mathrm{L}$ buffer).

4. Homogenize the mixture by Pellet Pestle Motor for $3 \times 10 \mathrm{sec}$ (see Note 2)

5. Centrifuge the homogenate at $4{ }^{\circ} \mathrm{C}$ for $10 \mathrm{~min}$ at $10000 \mathrm{~g}$, and collect the supernatant, and store at $-80^{\circ} \mathrm{C}$ for maximum 1 month.

6. Measure protein concentration by a BCA kit. Usually $20 \times$ dilution of tissue homogenates is required.

Preparing perfusate samples 
1. In case of perfusate sample, use Amicon Ultra $30 \mathrm{kDa}$ concentrating tubes to concentrate $4 \times 3 \mathrm{~mL}$ perfusate sample to $50-100 \mu$ l.

2. Pour $3 \mathrm{~mL}$ perfusate in the concentrating insert of an Amicon tube.

3. Put concentrating insert into the tube and close it. Spin samples at $7500 \times \mathrm{g}$ for $20 \mathrm{~min}, 4^{\circ} \mathrm{C}$

4. Remove the concentrating insert and discard the flow through from the tube. Reinsert the concentrating insert.

5. Pour $3 \mathrm{~mL}$ perfusate in the insert, recap and spin it for $20 \mathrm{~min}$. Repeat steps 3 4 twice more.

6. Pipette out the concentrated sample from the insert into an Eppendorf tube.

7. Measure protein concentration by BCA kit. Usually $3 \times$ dilution of perfusate concentrates is required.

\section{Cell culture lysates}

1. For cell culturing see ref. (30) (culturing neonatal cardiac myocytes)

2. Remove treating solutions and wash cells in $2 \mathrm{~mL}$ PBS two times, then remove PBS.

3. Scrape cells from 2 wells of a 6 -well plate in $200 \mu \mathrm{L}$ zymography homogenization buffer ( 2 wells together are $400 \mu \mathrm{L}$ and they are collected into 1 tube after washing both wells). In case of $25 \mathrm{~cm}^{2}$ flask use $400 \mu \mathrm{L}$ buffer, in case of $75 \mathrm{~cm}^{2}$ flask, use $1 \mathrm{~mL}$ buffer.

4. Keep Eppendorf tubes with the suspensions on ice and take into $-80^{\circ} \mathrm{C}$ freezer or concentrate them freshly.

\subsection{Concentration of samples}

1. Keep samples on ice.

2. Homogenize the mixture by ultrasonic homogenizer $2 \times 5 \mathrm{sec}$ on ice. 
3. Centrifuge cell homogenates at $5000 \times \mathrm{g}$ for $10 \mathrm{~min}$ at $4^{\circ} \mathrm{C}$.

4. Collect supernatant.

5. Centrifuge the supernatant in Amicon Ultra $10 \mathrm{kDa}$ concentrating tubes to increase the sample protein concentration $\left(4000 \times \mathrm{g}\right.$ for $30-50$ min at $\left.-4^{\circ} \mathrm{C}\right)$

6. Put $50-100 \mu \mathrm{L}$ samples into $-80^{\circ} \mathrm{C}$ freezer in 2 aliquots (1 aliquot for determination of protein concentration).

7. Measure protein concentration by BCA kit. Usually $3 \times$ dilution of cell concentrates is required.

\subsection{Preparation of separating gel}

1. Preparation of substrate for electrophoresis

\section{a) gelatin solution}

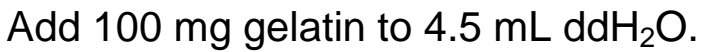

Gently heat and mix solution until it dissolves (beaker will be warm to touch, max. $40^{\circ} \mathrm{C}$ ). If it has cooled down, add $0.5 \mathrm{~mL} 10 \%(\mathrm{w} / \mathrm{v})$ SDS aqueous solution to reach final desired volume and concentration. Prepare freshly. (Note 3)

b) casein solution

Dissolve $100 \mathrm{mg}$ casein in $4.5 \mathrm{~mL}$ phosphate buffer.

Stir until casein dissolves.

Preparation of phosphate buffer: mix $7.12 \mathrm{~g} \mathrm{Na}_{2} \mathrm{HPO}_{4}$ dissolved in $400 \mathrm{~mL}$

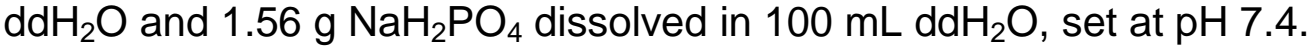

Add $0.5 \mathrm{~mL} 10 \% \mathrm{w} / \mathrm{v}$ SDS aqueous solution to reach final desired volume. OR

Dissolve $30 \mathrm{mg}$ casein in $2 \mathrm{~mL}$ of $75 \mathrm{mM}$ Tris $\mathrm{HCl}, \mathrm{pH}=8.8$ 


\section{c) elastin solution}

Add $54 \mathrm{mg} \mathrm{K}$-elastin to $4.5 \mathrm{~mL} \mathrm{H} \mathrm{H}_{2} \mathrm{O}$

Stir until elastin dissolves.

Add $0.5 \mathrm{~mL} 10 \% \mathrm{w} / \mathrm{v}$ SDS aqueous solution to reach final desired volume.

2. Assemble electrophoresis unit. (Note 4)

3. Mark desired level of separating gel on unit (use comb).

4. Mix $30 \%$ acrylamide/0.8\% bisacrylamide solution with Tris $\mathrm{HCl}, \mathrm{pH} 8.8$, gelatin solution and $\mathrm{dd}_{2} \mathrm{O}$ (Table 2).

5. Add $10 \%$ APS solution and TEMED to the mix quickly (Table 2 )

6. Swirl to get homogenous gel. Avoid bubbling. Use immediately as polymerization process has begun. (Note 5)

7. Using a pipette, pour a small amount into sandwich plates and watch for leakage. In the absence of leakage, continue filling up to $1 \mathrm{~mm}$ above line.

8. Gently add butanol (with a $27 \mathrm{G}$-needle connected to a $10-\mathrm{mL}$ syringe) along top to remove bubbles. (Note 6)

9. Allow gels to polymerize (approximately $20 \mathrm{~min}$ at $25^{\circ} \mathrm{C}$ ). Use this time to prepare stacking gel (without adding TEMED and 10\% APS) (Note 7)

10.A layer of $\mathrm{H} 2 \mathrm{O}$ on top of the gel will be visible when polymerization is complete. Drain this layer from the unit with a small stripe of blotting paper.

\subsection{Preparation of stacking gel}

1. Mix $30 \%$ acrylamide $/ 0.8 \%$ bisacrylamide solution with Tris $\mathrm{HCl}, \mathrm{pH} 6.8$ and $\mathrm{dd}_{2} \mathrm{O}$ (Table 3).

2. Add $10 \%$ SDS, $10 \%$ APS and TEMED quickly (Table 3 ). 
3. Swirl to mix. Avoid bubbling. Use immediately as polymerization process has begun.

4. Place comb in units and then use pipettes to pour stacking gel.

5. Allow gels to polymerize (approximately $15 \mathrm{~min}$ at $25^{\circ} \mathrm{C}$ ). Use this time to make sample calculation.

\subsection{Sample calculation}

1. According to the results of protein measurement, sample loading mass and volume should be calculated.

2. From a tissue homogenate, $50 \mu \mathrm{g}$ protein per lane should be loaded. Since we load $15 \mu \mathrm{l}$ per lane, this means that the final protein concentration of sample needs to be $50 \mu \mathrm{g} / 15 \mu \mathrm{l}$.

3. In case you want to load a sample only once, it is enough to prepare $2 \times$ volume of one load $(30 \mu \mathrm{l})$, which means that we should add $6 \mu \mathrm{l}(1 / 5$ part $)$ "pink" or $20 \mu \mathrm{l}$ (2/3 part) "blue" loading buffer.

4. The remaining $24 \mu \mathrm{l}$ or $10 \mu \mathrm{l}$, respectively, should contain $2 \times 50 \mu \mathrm{g}=100 \mu \mathrm{g}$ protein. Therefore, volume of the sample will be: $\mathrm{V}_{1}=100 \mu \mathrm{g} /$ protein concentration of your sample.

5. Then we should add $d d \mathrm{H}_{2} \mathrm{O}$ to dilute samples. The required volume of $d d \mathrm{H}_{2} \mathrm{O}$ is: $\mathrm{V}_{2}=30-\mathrm{V}_{1}$.

Taken together:

Loading volume: $\quad 15 \mu$

Loaded protein: $\quad 50 \mu \mathrm{g}$

Prepared volume: $\quad 30 \mu \mathrm{l}(2 \times$ Loading volume $)$

Prepared (sample) mass: $2 \times$ Loaded protein $(100 \mu \mathrm{g})$ 
"Pink" loading buffer: $\quad$ 1/5 of prepared volume $(6 \mu \mathrm{l})$ OR

"Blue" loading buffer: $\quad$ 2/3 of prepared volume $(20 \mu \mathrm{l})$

Sample volume: $\quad V_{1}=2 \times$ loaded protein $(2 \times 50 \mu \mathrm{g}) /$ sample protein concentration $(\mu \mathrm{g} / \mu \mathrm{L})$

$\mathrm{ddH}_{2} \mathrm{O}: \quad \mathrm{V}_{2}=$ Prepared volume $(30 \mu \mathrm{l})-\mathrm{V}_{1}$

\subsection{Sample loading and running gels}

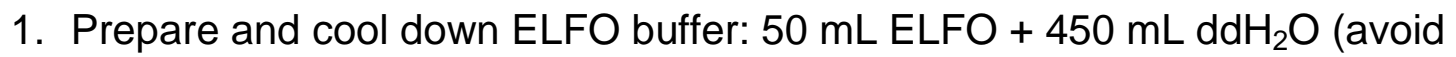
bubbles, mix gently, cool down). (Note 10)

2. Mark gel lanes for sample loading. Do not use the two outside lanes.

3. When gel is polymerized, remove combs by pulling straight up.

4. Remove gel plates and snap onto electrode assembly. (Note 11)

5. Fill up the lower and the upper buffer container with tank buffer.

6. In case of casein zymography: pre-run electrophoresis at $40 \mathrm{mV}$ for $15 \mathrm{~min}$ at $4^{\circ} \mathrm{C}$ before the samples are loaded into the wells. Another possibility is to load sample buffer into one well and pre-run electrophoresis at $4^{\circ} \mathrm{C}$ until it reaches the bottom of the gel. Afterwards continue with step 7, but keep gels at $4^{\circ} \mathrm{C}$. (Note 12).

7. Load samples

For identification of different isoforms of detected MMPs, positive controls (e.g. zymography standard containing human MMP-2 and -9 or MMP-2 standard.) should be used. Page ruler is also useful to detect the different size of bands. Leave one lane loaded with sample for negative control (see in section 3.6).

8. Connect electrodes properly (red to red, black to black) and set voltage at 90 V. 
9. For $8 \%$ gel run till dye gets until the bottom of gel. (Note 13)

10.Use this time to prepare renaturation solution and development buffer.

\subsection{Washing and incubating gels}

1. Set dry incubator at $37^{\circ} \mathrm{C}$.

2. Disassemble gel apparatus.

3. Cut down lane for negative control. (Note 14)

4. Wash gels for $40 \mathrm{~min}$ in $200 \mathrm{~mL}$ Renaturation solution at room temperature. (Note 15, 16)

5. Wash gels for $20 \mathrm{~min} 200 \mathrm{~mL}$ Development buffer. (Note 15, 16)

6. Place gels in fresh $200 \mathrm{~mL}$ development buffer. (Note 16) For negative control, incubate lane separately in 10 mM EGTA solution.

7. Incubate gels into dry incubator at $37^{\circ} \mathrm{C}$ for $20-40 \mathrm{~h}$. (Even before staining, gelatinolytic activity should be visible, if not, longer incubation should be applied). (Note 17)

\subsection{Staining gels and preparation for evaluation of MMP activity}

1. Even before staining, gelatinolytic activity should be visible (hold the gel up against a dark background to visualize).

2. Put gels in Coomassie Brilliant Blue solution. Place on a shaker for $1 \mathrm{~h}$. (Note 18)

3. Put gels in destaining solution. Place on shaker (at least $40 \mathrm{~min}$ ). (Note 19, 20)

4. Gelatinolytic activities should be detected as transparent bands against the blue background of Coomassie Brilliant Blue stained gelatin (see Figures 1-3).

5. Scan the gel in transparent mode with a special gel scanner. 
6. Evaluate MMPs activity by using a gel/film evaluation software (e.g. Quantity one, Bio-Rad)

\subsection{In situ zymography}

The present description provides details for performing in situ zymography for MMP-2 in cardiac myocytes (Fig. 3), however, techniques for showing other MMP activities in different tissue sections or cell cultures in situ are also existing and a description for general in situ zymographies is available in ref. (31).

1. Culture neonatal rat cardiac myocytes (30) or other cell types in 24-well tissue culture plate at the density of $10^{5}$ cells/well for 3 days.

2. Replace the growth medium (DMEM supplemented with Glu, AB/AM, 1\%FBS) with a "stress" solution containing DQ substrate at $40 \mu \mathrm{g} / \mathrm{mL}$ concentration. In case of control group, replace the medium of the cells with a control solution containing DQ substrate at the abovementioned concentration.

3. Subject cells to circumstances according to your aim/project, which may induce intracellular MMP-2 activation.

4. For negative control samples, use ilomastat (at $0.5 \mu \mathrm{M}$ final concentration), or other non-specific MMP inhibitor (e.g. 1,10-o-pheanthroline at 1-5 mM final concentration, SB-3CT at 1-10 nM final concentration).

5. Subsequently, replace "stress" solution with growth medium containing DQ substrate at $40 \mu \mathrm{g} / \mathrm{mL}$ concentration (250ul volume must be applied onto the cells).

6. Replace the medium, and wash cells twice with D-PBS. 
7. Rinse cells in $3.7 \%$ PFA in PBS at room temperature for 15 min.

8. Wash cells twice with PBS.

9. Rinse coverslips with mounting medium and view fluorescent signal under fluorescent microscope.

10. If it is necessary you can combine in situ zymography with immunocytochemistry. In this case after the fixation you should continue with an appropriate immunostaining protocol. 


\section{Notes}

1 Avoid reducing agents (e.g. dithiothreitol; DTT) or protease inhibitors (e.g. phenylmethanesulfonyl fluoride; PMSF) in the homogenization buffer. They may reduce or inhibit MMP activities, thereby may lead to false results.

2 Avoid ultrasonic homogenator. It can destroy the native structure of MMPs, therefore enzymes lost their activities.

3 Gelatin is very sensible. Make sure that gelatin dissolves completely (clear, transparent solution without any opalescent particle). By cooling avoid gel formation (too long cooling). When SDS is added, avoid precipitation. If gelatin precipitates, try to heat again. If precipitates will not disappear from the solution, make a new gelatin solution. Precipitated gelatin does not polymerize homogenously in the gel and leads irrelevant results in the enzyme activity.

4 In order to avoid leakage, ensure that spacers, comb and glass plates are aligned properly.

5 Make sure that gel is horizontal and there is no difference in the levels of the two edges.

6 Avoid "shooting" the butanol, and butanol covers the hole top surface of the gel uniformly.

7 TIP: leave pipette tip in the left over separating gel, when it is polymerized you will be able to lift it with the pipette.

8 Mix $15.0 \mathrm{~mL}$ of separating gel. This volume is sufficient for 1 small unit (contains 10 lanes) (i.e. 2 gels), or for 1 triple-wide unit (contains 30-33 lanes) mix $22.5 \mathrm{~mL}$.

$97.5-10 \%$ polyacrylamide gels are recommended for gelatin zymography. For casein zymography, we recommend to use $10-15 \%$ gels according to the MW of active MMP-7 (19-21kDa; 28-30 kDa pro-MMP-7). 
10 Calculate the necessary volume of ELFO buffer according the used buffer tank.

11 Eliminate bubbles under the gel, they may disturb gel running.

12 Casein migrates in gel during electrophoresis. Due to its low molecular weight (23 $\mathrm{kDa}$ ) the zone containing casein can obscure MMP-7 (latent form - $29 \mathrm{kDa}$, active form - $20 \mathrm{kDa}$ ) after staining. Therefore pre-run of casein-embedded gel is recommended before classical zymogram procedure in order to get excess of casein out of the gel. The amount of remaining casein is sufficient for detection of MMP activities (32).

13 Average time for gel running: 1.5-2 hours.

14 Avoid gel rupture. Cut the different corner of the gels to be able to identify the gels later (e.g. cut the bottom left corner of gel \#1, and both the top and bottom left corners for gel \#2. (Ensure that the gel is oriented correctly so that you don't accidentally cut the right side corner)

15 Before preparation of Renaturation and Development buffer, make sure, that the buffers do not contain any visible contamination (e.g. fungal particles). Buffers should be clear and transparent.

16 Make sure that gels immerse in the buffers and are not attached to the wall of the dish.

17 20-hour incubation is recommended for lung samples, 40-hour for heart samples. Individual differences may occur, therefore the authors recommend to run a pilot zymography for set up incubation time.

18 Staining can be longer, if it is necessary. The gel should be dark blue.

19 Use clear dish and change destaining solution after a couple of minutes (5-10 $\min )$, if it becomes bluish. 
20 Leave the gel in destaining solution until the stacking gel become completely destained (transparent) again (Fig .1 and 3). It can last even for 12 hours.

\section{Acknowledgements}

This work (P Bencsik, A Görbe) was supported by the János Bolyai Research Scholarship of the Hungarian Academy of Sciences and has received funding from the European Union's Horizon 2020 research and innovation programme under grant agreement No 698297 Acronym: Infarnosys. P. Ferdinandy was a Szentágothai Fellow of the National Excellence Program of Hungary (TÁMOP-4.2.4.A/ 2-11/12012-0001). 


\section{References}

1 Dormán G, Cseh S, Hajdú I, Barna L, Kónya D, Kupai K, et al (2010) Matrix metalloproteinase inhibitors: a critical appraisal of design principles and proposed therapeutic utility. Drugs 70(8):949-64

2 Kupai K, Szucs G, Cseh S, Hajdu I, Csonka C, Csont T et al (2010) Matrix metalloproteinase activity assays: Importance of zymography. J Pharmacol Toxicol Methods 61(2):205-209

3 Apte SS and Parks WC (2015) Metalloproteinases: A parade of functions in matrix biology and an outlook for the future. Matrix Biol 44-46:1-6

4 DeCoux A, Lindsey ML, Villarreal F, Garcia RA, Schulz R (2014) Myocardial matrix metalloproteinase-2: inside out and upside down. J Mol Cell Cardiol 77:6472

5 Nagase $\mathrm{H}$ and Woessner Jr JF (1999) Matrix metalloproteinases. J Biol Chem 274: $21491-21494$

6 Massova I, Kotra LP, Fridman R, Mobashery S (1998) Matrix metalloproteinases: structures, evolution, and diversification. FASEB J 12(12):1075-1095

7 Wang W, Schulze CJ, Suarez-Pinzon WL, Dyck JR, Sawicki G, Schulz R (2002) Intracellular action of matrix metalloproteinase-2 accounts for acute myocardial ischemia and reperfusion injury. Circulation 106:1543-1549

8 Gao CQ, Sawicki G, Suarez-Pinzon WL, Csont T, Wozniak M, Ferdinandy P et al (2003) Matrix metalloproteinase-2 mediates cytokine-induced myocardial contractile dysfunction. Cardiovasc Res 57(2):426-433

9 Spinale FG (2002) Matrix metalloproteinases: regulation and dysregulation in the failing heart. Circ Res 90(5):520-530 
10 Gruber BL, Sorbi D, French DL, Marchese MJ, Nuovo GJ, Kew RR et al (1996) Markedly elevated serum MMP-9 (gelatinase B) levels in rheumatoid arthritis: a potentially useful laboratory marker. Clin Immunol Immunopathol 78(2):161-171

11 Mukherjee A and Swarnakar S (2015) Implication of matrix metalloproteinases in regulating neuronal disorder. Mol Biol Rep 42(1):1-11

12 Li M, Yamamoto H, Adachi Y, Maruyama Y, Shinomura Y (2006) Role of matrix metalloproteinase-7 (matrilysin) in human cancer invasion, apoptosis, growth, and angiogenesis. Exp Biol Med (Maywood) 231(1):20-27

13 Kurzepa J, Mądro A, Czechowska G, Kurzepa J, Celiński K, Kazmierak W et al (2014) Role of MMP-2 and MMP-9 and their natural inhibitors in liver fibrosis, chronic pancreatitis and non-specific inflammatory bowel diseases. Hepatobiliary Pancreat Dis Int 13(6):570-579

14 Craig VJ, Zhang L, Hagood JS, Owen CA (2015) Matrix Metalloproteinases as Therapeutic Targets for Idiopathic Pulmonary Fibrosis. Am J Respir Cell Mol Biol 53(5):585-600

15 Meschiari CA, Marcaccini AM, Santos Moura BC, Zuardi LR, Tanus-Santos JE, Gerlach RF (2013) Salivary MMPs, TIMPs, and MPO levels in periodontal disease patients and controls. Clin Chim Acta 421:140-146

16 Ivanova M, Dovinova I, Okruhlicova L, Tribulova N, Simoncikova P, Bartekova M et al (2012) Chronic cardiotoxicity of doxorubicin involves activation of myocardial and circulating matrix metalloproteinases in rats. Acta Pharmacol Sin 33(4):459469

17 Bartekova M, Simoncikova P, Fogarassyova M, Ivanova M, Okruhlicova L, Tribulova N et al (2015) Quercetin improves postischemic recovery of heart function in doxorubicin-treated rats and prevents doxorubicin-induced matrix 
metalloproteinase-2 activation and apoptosis induction. Int J Mol Sci 16(4):81688185

18 Barancik M, Okruhlicova L, Fogarassyova M, Bartekova M, Slezak J (2013) Mediastinal irradiation modulates myocardial and circulating matrix metalloproteinases. Exp Clin Cardiol 18S: 37A-40A

19 Cheung PY, Sawicki G, Wozniak M, Wang W, Radomski MW, Schulz R (2000) Matrix metalloproteinase-2 contributes to ischemia-reperfusion injury in the heart. Circulation 101(15):1833-9

20 Lalu MM, Csonka C, Giricz Z, Csont T, Schulz R, Ferdinandy P (2002) Preconditioning decreases ischemia/reperfusion-induced release and activation of matrix metalloproteinase-2. Biochem Biophys Res Commun 296(4):937-941

21 Bencsik P, Kupai K, Giricz Z, Görbe A, Pipis J, Murlasits Z et al (2010) Role of iNOS and peroxynitrite - matrix metalloproteinase-2 signaling in myocardial late preconditioning in rats. Am J Physiol Heart Circ Physiol 299(2):512

22 Bencsik P, Paloczi J, Kocsis GF, Pipis J, Belecz I, Varga ZV et al (2014) Moderate inhibition of myocardial matrix metalloproteinase- 2 by ilomastat is cardioprotective. Pharmacol Res 80:36-42

23 Bencsik P, Sasi V, Kiss K, Kupai K, Kolossváry M, Maurovich-Horvat P et al (2015) Serum lipids and cardiac function correlate with nitrotyrosine and MMP activity in coronary artery disease patients. Eur J Clin Invest 45(7):692-701

24 Bautista-López NL and Schulz R (2014) Matrix metalloproteinases 2 and 9 as diagnostic tools in Chagas cardiomyopathy. Int J Cardiol 177(1):46-7

25 Zhang $\mathrm{Y}$, Lin $\mathrm{P}$, Jiang $\mathrm{H}, \mathrm{Xu} \mathrm{J}$, Luo S, Mo J et al (2015) Extensive serum biomarker analysis in patients with ST segment elevation myocardial infarction (STEMI). Cytokine 76(2):356-62 
26 Mook OR, Frederiks WM, Van Noorden CJ (2004) The role of gelatinases in colorectal cancer progression and metastasis. Biochim Biophys Acta 1705(2):6989

27 Annaházi A, Molnár T, Farkas K, Rosztóczy A, Izbéki F, Gecse K et al (2013) Fecal MMP-9: a new noninvasive differential diagnostic and activity marker in ulcerative colitis. Inflamm Bowel Dis 19(2):316-20

28 Arpino V, Brock M, Gill SE (2015) The role of TIMPs in regulation of extracellular matrix proteolysis. Matrix Biol 44-46:247-254

29 Troeberg L and Nagase H (2007) Analysis of TIMP expression and activity. Methods Mol Med 135:251-67

30 Gorbe A, Giricz Z, Szunyog A, Csont T, Burley DS, Baxter GF et al (2010) Role of cGMP-PKG signaling in the protection of neonatal rat cardiac myocytes subjected to simulated ischemia/reoxygenation. Basic Res Cardiol 105(5):643-50

31 Yan SJ and Blomme EA (2003) In situ zymography: a molecular pathology technique to localize endogenous protease activity in tissue sections. Vet Pathol 40(3):227-36

32 Fernandez-Resa P, Mira E, Quesada AR (1995) Enhanced detection of casein zymography of matrix metalloproteinases. Anal Biochem 224(1):434-435

33 Roomi MW, Kalinovsky T, Rath M, Niedzwiecki A (2014) Effect of a nutrient mixture on matrix metalloproteinase-9 dimers in various human cancer cell lines. Int J Oncol 44(3):986-92 


\section{Figure legends}

Figure 1: Representative gelatin zymograms performed from human samples. Panel A: Human serum samples from patients with coronary artery disease. Some of the patients have increased MMP-2 and/or MMP-9 activity as indicated by the zymographic intensity at 72 or 86 kDa, respectively. Panel B: Gelatin zymogram from human isolated lymphocytes. 72 kDa-MMP-2 activity is markedly visible, however, other activities at 64 (MMP-2) and at $86 \mathrm{kDa}$ (MMP-9) can also be observed. Weak gelatinolytic activity signals can be seen in both panels at $192 \mathrm{kDa}$, which may indicate the dimerized form of MMP-9 (33) (Roomi et al., 2014).

Figure 2: Representative gelatin zymograms performed from homogenates of murine tissues (L1-4: lanes 1-4; $15 \mu \mathrm{g}$ protein was loaded into each wells). Panel A represents mouse heart homogenates, which expresses mainly the 72-kDa isoform of MMP-2. Weak signal for MMP-9 can be observed, however, it indicates inappropriate removal of blood from heart samples. Panel B: lung samples from mice subjected to chronic tobacco smoking (L2 and 4) and their controls (L1 and 3). A markedly increased intensity can be observed at 92 kDa (MMP-9). Panel C: Samples derived from the aorta of transgenic mice. L1-2: ApoB100LDL-/- mice, control and Chlamydia pneumoniae (Cpn) infected; L3-4: ApoE-/-, control and Cpn infected.

Figure 3: Examples of MMP zymography y in isolated and/or cultured cells. Panel A: gelatin zymogram from cultured neonatal cardiac myocytes after resuspension. Gelatinolytic activities can be detected at completely different molecular weights than that of heart homogenates (for comparison see Fig 2A). Panel B and C: In situ gelatin 
zymography in fixed neonatal cardiac myocyte culture in normoxic conditions (Panel B) and subjected to simulated ischemia/reoxygeation (Panel C). Panel C shows an increased gelatinolytic activity (represented as green fluorescence - DQ ${ }^{\mathrm{TM}}$ fluorescent gelatin; red fluorescence: MMP-2 immunostaining by rhodamine-labeled goat antimouse antibody, blue fluorescence: cell nuclei by Hoechst 33342 staining) in cardiac myocytes, which indicates the presence and activation of MMP-2 during simulated ischemic stress. Scale bars $=20 \mu \mathrm{m}$. 
Table 1: The family of MMPs and their characteristic features.

\begin{tabular}{|c|c|c|c|c|c|}
\hline \multirow{2}{*}{$\begin{array}{l}\text { MMP } \\
\text { codes }\end{array}$} & \multirow{2}{*}{$\begin{array}{l}\text { Alternative } \\
\text { names }\end{array}$} & \multicolumn{2}{|c|}{$\begin{array}{l}\text { Molecular } \\
\text { weight (kDa) }\end{array}$} & \multirow{2}{*}{ Substrates } & \multirow{2}{*}{ Pathologies } \\
\hline & & $Z^{*}$ & $A^{*}$ & & \\
\hline MMP-1 & $\begin{array}{l}\text { interstitial } \\
\text { collagenase }\end{array}$ & 57 & 52 & gelatin & $\begin{array}{l}\text { atherosclerosis, melanoma, heart } \\
\text { failure }\end{array}$ \\
\hline MMP-2 & $\begin{array}{l}\text { gelatinase A, type } \\
\text { IV collagenase }\end{array}$ & $75 / 72$ & 64 & gelatin, elastin & $\begin{array}{l}\text { myocardial infarction, heart failure, } \\
\text { gastritis, rheumatoid arthritis }\end{array}$ \\
\hline MMP-3 & stromelysin-1 & 57 & 45 & $\begin{array}{l}\text { gelatin, } \\
\text { elastin, casein }\end{array}$ & brain injury, neurodegeneration \\
\hline MMP-7 & matrilysin & 28 & 19 & $\begin{array}{l}\text { gelatin, } \\
\text { elastin, casein }\end{array}$ & $\begin{array}{l}\text { tumor-induced osteolysis, colon } \\
\text { cancer }\end{array}$ \\
\hline MMP-8 & $\begin{array}{l}\text { neutrophil } \\
\text { collagenase }\end{array}$ & 75 & 57 & gelatin & coronary artery disease, angina \\
\hline MMP-9 & gelatinase B & 92 & 86 & gelatin, elastin & $\begin{array}{l}\text { myocarditis and subsequent dilated } \\
\text { cardiomyopathy, ulcerative colitis }\end{array}$ \\
\hline MMP-10 & stromelysin-2 & 57 & 44 & $\begin{array}{l}\text { gelatin, } \\
\text { elastin, casein }\end{array}$ & lung cancer \\
\hline MMP-11 & stromelysin-3 & 51 & 44 & $\begin{array}{l}\text { gelatin, } \\
\text { elastin, casein }\end{array}$ & $\begin{array}{l}\text { tumor progression, breast } \\
\text { carcinomas }\end{array}$ \\
\hline MMP-12 & $\begin{array}{l}\text { macrophage } \\
\text { metalloelastase }\end{array}$ & 54 & 22 & $\begin{array}{l}\text { gelatin, } \\
\text { elastin, casein }\end{array}$ & $\begin{array}{l}\text { granulomatous skin diseases, } \\
\text { inflammatory disorders }\end{array}$ \\
\hline MMP-13 & collagenase-3 & 65 & 48 & gelatin & breast carcinomas \\
\hline MMP-14 & MT1-MMP & 66 & 54 & gelatin, casein & tumor growth by activating MMP-2 \\
\hline MMP-15 & MT2-MMP & 76 & $N / A$ & $\begin{array}{l}\text { fibronectin. } \\
\text { laminin }\end{array}$ & $\begin{array}{l}\text { obesity, pre-eclampsia, ovarian } \\
\text { carcinoma }\end{array}$ \\
\hline MMP-16 & MT3-MMP & 64 & $52 / 30$ & gelatin, casein & breast cancer \\
\hline MMP-17 & MT4-MMP & 71 & 67 & N/A & pre-eclampsia \\
\hline MMP-19 & RASI-1 & 57 & $N / A$ & gelatin & rheumatoid arthritis \\
\hline MMP-20 & enamelysin & 54 & 42.5 & & amelogenesis imperfecta \\
\hline MMP-21 & N/A & N/A & $\mathrm{N} / \mathrm{A}$ & N/A & $\begin{array}{l}\text { melanoma, ovarian and colon } \\
\text { carcinomas }\end{array}$ \\
\hline MMP-22 & N/A & $\mathrm{N} / \mathrm{A}$ & 42 & $N / A$ & N/A \\
\hline MMP-23 & $\mathrm{N} / \mathrm{A}$ & $\mathrm{N} / \mathrm{A}$ & $\mathrm{N} / \mathrm{A}$ & $\mathrm{N} / \mathrm{A}$ & breast cancer \\
\hline MMP-24 & MT5-MMP & N/A & $\mathrm{N} / \mathrm{A}$ & N/A & brain tumors \\
\hline MMP-25 & $\begin{array}{l}\text { MT6-MMP, } \\
\text { leucolysin }\end{array}$ & 56 & 38 & pro-MMP-2 & inflammatory hyperalgesia \\
\hline MMP-26 & endometase & 29 & 19 & gelatin & lung cancer \\
\hline
\end{tabular}

${ }^{*} \mathrm{Z}$ and $\mathrm{A}$ indicates the zymogen or active form(s) of MMPs, respectively. 
Table 2: Preparation of separating gel between 0.75-1.5 mm thickness (Note 8,9 )

\begin{tabular}{|c|c|c|c|c|c|c|}
\hline \multirow[b]{3}{*}{ STOCK SOLUTIONS } & \multicolumn{6}{|c|}{$\begin{array}{l}\text { Final acrylamide concentration in the separating } \\
\qquad \text { gel (\%) }\end{array}$} \\
\hline & \multirow[t]{2}{*}{7.0} & \multirow[t]{2}{*}{7.5} & \multicolumn{2}{|c|}{8.0} & \multirow[t]{2}{*}{9.0} & \multirow[t]{2}{*}{10.0} \\
\hline & & & $\begin{array}{l}\text { small gel } \\
(15 \mathrm{~mL})\end{array}$ & $\begin{array}{l}\text { large gel } \\
(22.5 \mathrm{~mL})\end{array}$ & & \\
\hline $\begin{array}{l}\text { 30\% acrylamide / 0.8\% bisacrylamide } \\
(\mathrm{mL})\end{array}$ & 3.5 & 3.75 & 4.0 & 6 & 4.5 & 5.0 \\
\hline $1.5 \mathrm{M}$ Tris- $\mathrm{HCl}, \mathrm{pH} 8.8(\mathrm{~mL})$ & 3.75 & 3.75 & 3.75 & 5.62 & 3.75 & 3.75 \\
\hline $\mathrm{ddH} 2 \mathrm{O}(\mathrm{mL})$ & 6.25 & 6.0 & 5.75 & 8.62 & 5.25 & 4.75 \\
\hline $\begin{array}{l}\text { Gelatin/casein/elastin solution } \\
(20 / 20 / 12 \mathrm{mg} / \mathrm{mL}, 1 \% \mathrm{w} / \mathrm{v} \mathrm{SDS} ; \mathrm{mL})\end{array}$ & 1.5 & 1.5 & 1.5 & 2.25 & 1.5 & 1.5 \\
\hline $\begin{array}{l}\text { 10\% w/v Ammonium Persulfate } \\
\text { Solution (APS; } \mu \mathrm{L} \text { ) }\end{array}$ & 50 & 50 & 10 & 75 & 50 & 50 \\
\hline TEMED $(\mu \mathrm{L})$ & 10 & 10 & 10 & 15 & 10 & 10 \\
\hline
\end{tabular}


Table 3: Preparation of $5 \mathrm{~mL}$ stacking gel.

\begin{tabular}{|l|l|}
\hline STOCK SOLUTIONS & VOLUME \\
\hline $30 \%$ acrylamide/ 0.8\% bisacrylamide & $1 \mathrm{~mL}$ \\
\hline $0.5 \mathrm{M}$ Tris $\mathrm{HCl} \mathrm{pH} 6.8$ & $1.25 \mathrm{~mL}$ \\
\hline $\mathrm{ddH}_{2} \mathrm{O}$ & $3.05 \mathrm{~mL}$ \\
\hline $10 \% \mathrm{SDS}$ & $50 \mu \mathrm{L}$ \\
\hline $10 \% \mathrm{w} / \mathrm{v}$ Ammonium Persulfate Solution (APS) & $25 \mu \mathrm{L}$ \\
\hline TEMED & $8 \mu \mathrm{L}$ \\
\hline
\end{tabular}

